\title{
Video Game Addiction: Past, Present and Future
}

\author{
Mark D. Griffiths ${ }^{\mathrm{a}, *}$, Daria J. Kuss ${ }^{\mathrm{a}}$ and Daniel L. King ${ }^{\mathrm{b}}$ \\ ${ }^{a}$ International Gaming Research Unit, Psychology Division, Nottingham Trent University, Burton Street, Nottingham, \\ NG1 4BU, UK; ${ }^{b}$ School of Psychology, The University of Adelaide, South Australia, S.A., 5005, Australia
}

\begin{abstract}
Gaming addiction has become a topic of increasing research interest. The last decade has witnessed a significant increase in the number of empirical studies examining various aspects of problematic video game play and video game addiction. This paper begins with a brief past history of how research into video game addiction has changed over the last three decades (i.e., the 1980s, 1990s and 2000s). It then examines more thoroughly the contemporary research literature by analyzing the (i) prevalence of problematic video game use and video game addiction, (ii) negative consequences of excessive video game use, (iii) factors associated with problematic video game use and video game addiction, and (iv) the treatment of problematic video game use and video game addiction. The paper concludes by looking at the trends in the field and a somewhat theoretical examination of what the future of video game addiction might be.
\end{abstract}

Keywords: Video games; Video game addiction; Gaming addiction; Problematic video game use; Excessive gaming; Gaming addiction treatment.

\section{VIDEO GAME ADDICTION: PAST, PRESENT AND FUTURE}

\section{Introduction}

Gaming addiction has become a topic of increasing research interest. Over the last decade there has been a significant increase in the number of empirical studies examining various aspects of video game addiction compared to the preceding decade. This has resulted in a wide-ranging selection of review papers focusing on different aspects of the topic. These include general literature reviews of video game addiction [1-5], reviews of online (as opposed to offline) gaming addiction [6-8], reviews of the main methodological issues in studying video game addiction $[9,10]$, reviews of structural characteristics and their relationship with video game addiction [11,12], reviews of video game addiction treatment [13-16], reviews of video game addiction and co-morbidity/convergence with other addictions such as gambling addiction and Internet addiction [17-20], and miscellaneous review papers on very specific aspects of video game addictions such as social responsibility [21], screening instruments [22], or reviews refuting that video game addiction even exists [23].

It should also be noted that given the lack of consensus as to whether video game addiction exists and/or whether the term 'addiction' is the most appropriate to use, some researchers have instead used terminology such as 'excessive' or 'problematic' to denote the harmful use of video games [24]. Terminology for what appears to be the

*Address correspondence to this author at the International Gaming Research Unit, Psychology Division, Nottingham Trent University, Burton Street, Nottingham, NG1 4BU, UK; Tel: +44-115-8482401;

Fax: +44 (0)115848 2390; E-mail: mark.griffiths@ntu.ac.uk same disorder and/or its consequences include problem video game playing [25,26], problematic online game use [27], video game addiction [1,28], online gaming addiction [29,30], Internet gaming addiction [7], and compulsive Internet use [31]. This paper briefly examines a number of key areas in the study of problematic video game play and video game addiction. It begins with a brief past history of how research into video game addiction has changed over the last three decades. It then examines the present research by analyzing the (i) prevalence of problematic video game use and video game addiction, (ii) negative consequences of excessive video game use, (iii) factors associated with problematic video game use and video game addiction, and (iv) the treatment of problematic video game use and video game addiction. The paper concludes by looking at the trends in the field and a somewhat theoretical examination of what the future of video game addiction might be.

\section{GAMING ADDICTION: THE PAST}

\section{Gaming Addiction in the 1980s}

Following the release of the first commercial video games in the early 1970 s, it took until the 1980 s for the first reports of video game addiction to appear in the psychological and psychiatric literature. In the early 1980s, Ross, Finestone and Lavin [32] reported three cases of 'Space Invaders obsession' and Nilles [33] described a similar phenomenon but called it 'computer catatonia'. Arguably the first reference to 'video game addiction' was in 1983 by Soper and Miller [34], who, based on their observations as school counselors, claimed the disorder was like any other behavioral addiction and consisted of a compulsive behavioral involvement, a lack of interest in other activities, association and friendship circles mainly with other video game addicts, and physical and mental 
symptoms when attempting to stop the behavior (e.g., "the shakes"). Some credence was given to these claims that video game addiction existed following papers on the seemingly successful treatment of video game addiction using cognitive behavioral therapy $[35,36]$. However, all of these studies were somewhat observational, anecdotal, and/or case studies, primarily based on samples of teenage males, and all based on a particular type of video game using a particular medium (i.e., 'pay-to-play' arcade video games).

In 1989, Shotton [37] published the first empirical study specifically on gaming addiction on a relatively small sample of 127 people (almost all teenage or young adult males) who described themselves as "hooked" on home video games for at least five years. Shotton's conceptualization of game addiction was more positive than negative, and she reported that her 'addicts' were on the whole highly intelligent, motivated, and achieving people but often misunderstood by others in society. In relation to gaming addiction, the main problem with the study was that no standardized measure of addiction was actually used. The only criterion for being 'addicted' was the individual's own admission that they were 'hooked' on computer games. Despite this major shortcoming, recent research by Widyanto, Griffiths and Brunsden [38] reported that a person's self-diagnosis of whether they were addicted to the Internet or not correlated highly with more standardized measures of Internet addiction.

\section{Gaming Addiction in the 1990s}

The 1990s saw a small but significant increase of research into video game addiction with all of these studies being carried out in the UK and on adolescents typically surveying children in school settings [39-45]. In contrast to the early 1980s studies, these studies mainly examined nonarcade video game playing (i.e., home console games, handheld games, PC gaming). However, all of these studies were self-report surveys, relatively small scale and the main problem was that all of them assessed video game addiction using adapted versions of the DSM-III-R or DSM-IV criteria for pathological gambling [46]. Although there are clearly many similarities between gambling and video gaming, they are different behaviors and specific video game screening instruments should have been developed. Based on further analysis of the adapted DSM criteria used, these studies were later criticized as being more likely to be assessing video game preoccupation rather than video game addiction [47].

\section{Gaming Addiction in the 2000s}

The 2000s saw a substantial growth in the number of studies on video game addiction particularly as gaming expanded into the new online medium where games could be played as part of a gaming community (i.e., massively multiplayer online role playing games [MMORPGs] such as World of Warcraft and Everquest). Approximately sixty studies were published on gaming addiction between 2000 and 2010 [7] and a vast majority of these examined
MMORPG addiction and was not limited to the study of adolescent males. Furthermore, many of these studies collected their data online and a significant minority of studies examined various other aspects of video game addiction using non-self-report methodologies. These include studies using polysomnographic measures and visual and verbal memory tests [48], medical examinations including the patient's history, and physical, radiologic, intraoperative, and pathologic findings [49], functional Magnetic Resonance Imaging [50-52], electroencephalography [53], and genotyping [54].

Given the methodological shortcomings of the studies published prior to 2000, and the fact that gaming has evolved substantially over the last decade, the remainder of this review will mainly focus on studies published in the last decade (i.e., post-2000 papers) with the exception of those concerning the health and medical consequences of excessive video game play (as most of these are case studybased and the medical effects do not appear to be dependent on the medium in which the games are played).

\section{GAMING ADDICTION: THE PRESENT}

\section{Prevalence of Problematic Video Game Use and Video Game Addiction}

Table 1 presents a summary of prevalence studies examining problematic video gaming from 1994 to 2012. The studies were selected on the basis of having at least 300 participants, and using some kind of screening instrument to assess problematic video game playing (rather than selfdiagnosis). Estimated prevalence rates of problematic gaming range from $1.7 \%$ to over $10 \%$ among general samples. Prevalence rates among video game players were in some cases much higher (see Table 1). These studies also indicate that, in general, males are significantly more likely than females to report problems relating to their gaming. According to King and colleagues [15], the differences in methods of assessing game-based problems may partly account for differences in prevalence rates. Furthermore, many studies fail to assess prior problems (i.e., lifetime prevalence). King et al. [15] also noted that some studies do not consider subclinical cases (i.e., meeting some but not all criteria for problematic use), and the presence of co-morbid psychopathology is not routinely assessed.

From a substantive perspective, there are some generalizations that can be made with regard to the demographic characteristics of gamers and problem gamers. The literature, to date, suggests that adolescent males and young male adults appear to be at greater risk of experiencing problematic video game play. However, the course and severity of these problems is not well known [15] and the finding that this group is more at risk may be a consequence of sampling bias as well as the fact that this group plays video games more frequently than other sociodemographic groups. It has also been suggested that university students may be especially vulnerable to developing problematic video gaming. Reasons for this include their flexible tuition and study hours, ready access to high-speed broadband on a $24 / 7$ basis, and multiple stressors 
Table 1. Prevalence of "Video Game Addiction" in the Largest Survey Studies (1994-2012)

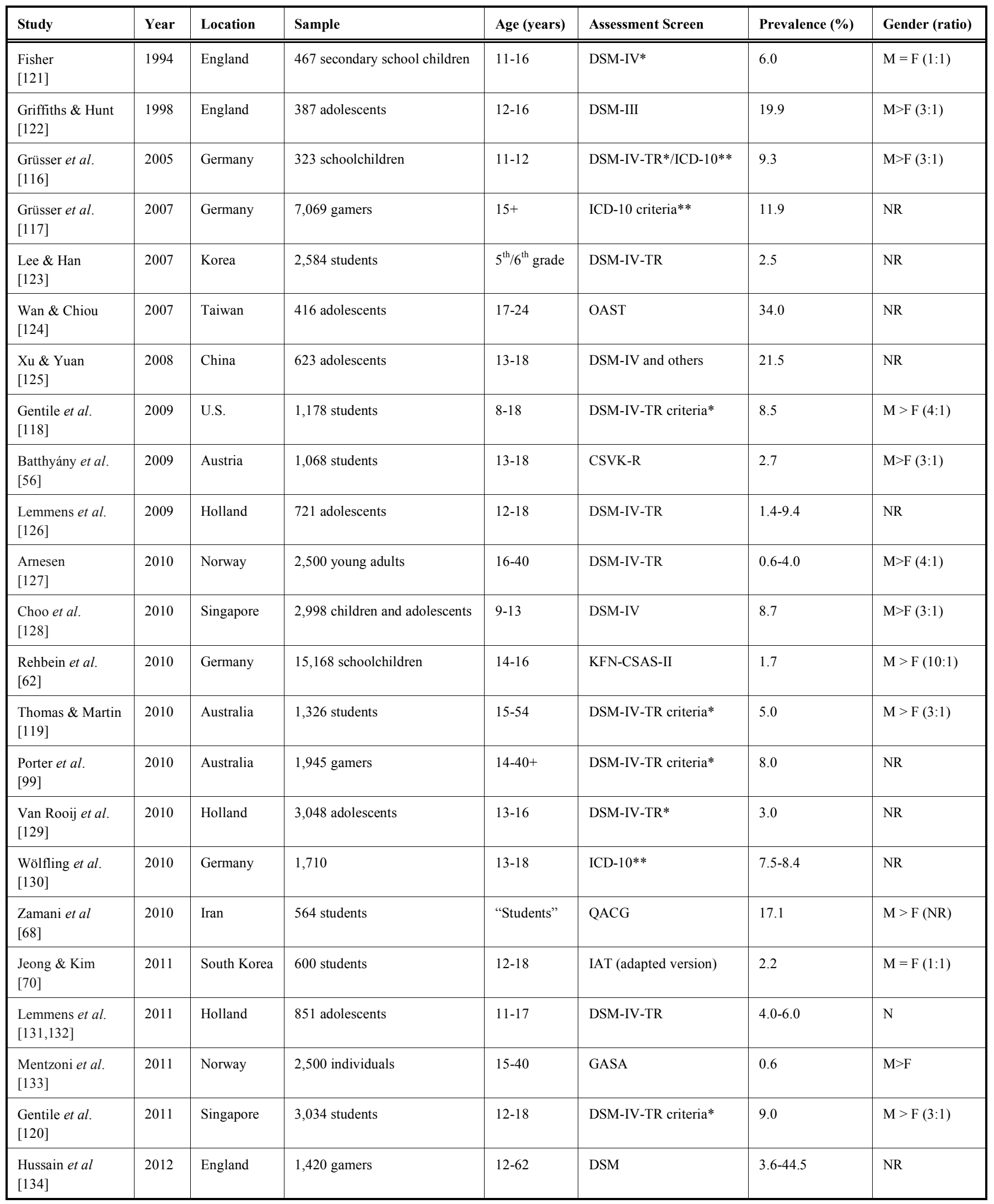

* Specific DSM-IV-TR criteria varied across studies. Adapted DSM-IV criteria for pathological gambling were used in several studies.

** Refers to symptoms of dependence described in the ICD-10.

Note: NR = Not reported; IAT = Internet Addiction Test KFN-CSAS-II = Video Game Dependency Scale; CSVK-R = Fragebogen zum Computerspielverhalten bei Kindern und

Jugendlichen; $\mathrm{QACG}=$ Questionnaire of Addiction to Computer Games 
associated with adjusting to new social obligations and/or living out-of-home for the first time $[15,55]$.

\section{Negative Consequences of Excessive Video Game Use}

Irrespective of whether problematic video game play can be classed as an addiction, there is now a relatively large number of studies all indicating that excessive video game play can lead to a wide variety of negative psychosocial consequences for a minority of affected individuals. These include sacrificing work, education, hobbies, socializing, time with partner/family, and sleep [56-64], increased stress [56], an absence of real life relationships [65], lower psychosocial well-being and loneliness [66], poorer social skills [67,68], decreased academic achievement [28,62, 69,70], increased inattention [56,71], aggressive/oppositional behavior and hostility [69,71], maladaptive coping [56,72,73], decreases in verbal memory performance [48], maladaptive cognitions [60], and suicidal ideation [62].

In addition to the reported negative psychosocial consequences, there are also many reported health and medical consequences that may result from excessive video game playing. These include epileptic seizures [74-79], auditory hallucinations [80], enuresis [81], encoprisis [82], obesity [83-86], wrist pain [87], neck pain [88], tenosynovitis - also called "nintendinitis" [89-92], blisters, calluses, sore tendons, and numbness of fingers [93], handarm vibration syndrome [94], sleep abnormalities [48,65], psychosomatic challenges [56], and repetitive strain injuries [95].

Taken together, this relatively long list of potential psychosocial and medical negative consequences clearly indicates that excessive gaming is an issue irrespective of whether it is an addiction. It also suggests that more extensive recognition by the medical community is needed of the wide range of potential negative and life-limiting consequences of excessive video play.

\section{Factors Associated with Problematic Video Game Use and Video Game Addiction}

A number of studies have examined the role of different personality factors, comorbidity factors, and biological factors, and their association with gaming addiction. In relation to personality traits, gaming addiction has been shown to have association with neuroticism $[61,96]$, aggression and hostility [69,96-98], avoidant and schizoid interpersonal tendencies [67], loneliness and introversion [97], social inhibition [99], boredom inclination [69], sensation-seeking [69,96], diminished agreeableness [61], diminished self-control and narcissistic personality traits [98], low self-esteem [100], state and trait anxiety [96], and low emotional intelligence [101]. Considering the relatively high frequency of co-occurring personality, comorbidity and biological factors, it is hard to assess the etiological significance of these associations with gaming addiction as they may not be unique to the disorder. Further research is therefore needed.

Research has also shown gaming addiction to be associated with a variety of comorbid disorders. These include attention deficit hyperactivity disorder [54,56,67,71], symptoms of generalized anxiety disorder, panic disorder, depression, social phobia [65], school phobia [56], and various psychosomatic symptoms [56].

Through use of fMRI, biological research has shown that gaming addicts show similar neural processes and increased activity in brain areas associated with substance-related addictions and other behavioral addictions, such as pathological gambling (significant activation in the left occipital lobe, parahippocampal gyrus, dorsolateral prefrontal cortex, nucleus accumbens, right orbitofrontal cortex, bilateral anterior cingulate, medial frontal cortex, and the caudate nucleus [50-52]. It has also been reported that gaming addicts (like substance addicts) have a higher prevalence of two specific polymorphisms of the dopaminergic system (i.e., Taq1A1 allele of the dopamine D2 receptor and the Val158Met in the Catecholamine-OMethyltransferase) [102], which suggests that among some players there might be some genetic predisposition to develop video game addiction.

\section{Treatment of Problematic Video Game Use and Video Game Addiction}

Clinical interventions and treatment for problematic and/or addictive video game play vary considerably in the literature, with most of the very few published studies employing some type of cognitive-behavioral therapy (CBT), pharmacotherapy, and/or self-devised psychological interventions [13-15,50,102]. Currently, the evidence base on the treatment of problematic and/or addictive gaming is limited. Furthermore, the lack of consistent approaches to treating problematic video game playing and video game addiction makes it difficult to produce any definitive conclusions as to the efficacy of treatment, although at this stage the effectiveness of CBT (as with the treatment efficacy of other addictions) appears to be supported by preliminary evidence [15].

Problematic cognitions are thought to maintain problematic gaming behaviors. Research on gamers has identified several attitudes and beliefs associated with excessive playing behavior. These include the belief that no amount of time spent playing is "long enough" that produces a need to continue playing a video game until every level, reward, or feature is completed [15]. Emotional responses associated with in-game rewards and completion of the video game encourage players to then seek out and begin playing new games, thus initiating a never-ending cycle of playing behavior [11,13]. Other common cognitive beliefs among problem video game players include thoughts about gaining power and status through the game, thoughts of mentally escaping from the real world, and thinking of the computer as a companion or "electronic friend" [15].

Motivational interviewing (MI) can be used as part of a therapeutic intervention. MI borrows strategies from cognitive therapy, client-centered counseling, systems theory, and the social psychology of persuasion, and contains elements of both directive and non-directive therapeutic approaches. It is based on theories of cognitive dissonance and attempts to promote a favorable attitude change. Briefly, 
instructing video game addicts of the problems of dependency and the advantages of abstinence tends to result in the addict making contradictory arguments. Motivational interviewing encourages clients to give their own reasons for attempting to change their problematic gaming behavior. The underlying theme of such a therapeutic approach is the issue of ambivalence (the mixed feelings the addict has to their behavior), and how the therapist can use MI to resolve it and allow the client to build commitment and reach a decision to change. Nevertheless, there remains a need for controlled and randomized, comparative studies of psychological and pharmacological treatments, administered individually and in combination with each other, to determine the optimal treatment approach.
The lack of comparative treatment studies might suggest that there is a general lack of demand for psychological services for problematic video game play and/or video game addiction [14]. However, this may not necessarily be the case. For instance, Woog [103] surveyed a random sample of 5000 US mental health professionals. Although only 229 participants completed the questionnaire that was used in this study, two-thirds had treated someone with excessive computer use problems in the year prior to the survey. Woog also reported that problematic gaming was most common among 11- to 17-year old clients. However, this client group may be more likely to present in therapy as anecdotal evidence suggests they are typically forced by concerned parents to attend treatment. Adult gaming addicts may not

Table 2. Selected Characteristics of Treatment Studies for Internet and Online Video Game Addiction

\begin{tabular}{|c|c|c|c|c|c|c|c|}
\hline Researcher(s) & Assessment & $\begin{array}{l}\text { Extent of Gaming } \\
\text { Problem in IA } \\
\text { Diagnosis }\end{array}$ & Conditions & $\mathbf{N}$ & $\begin{array}{l}\text { Age Range } \\
\text { (years) }\end{array}$ & Treatment Outcome & $\begin{array}{l}\text { Treatment } \\
\text { Effect Size }\end{array}$ \\
\hline $\begin{array}{l}\text { Du et al. (2010) } \\
{[107]}\end{array}$ & $\begin{array}{l}\text { Beard's Diagnostic } \\
\text { Questionnaire }\end{array}$ & $\mathrm{NC}$ & $\begin{array}{l}\text { 1. CBT (8 sessions) } \\
\text { 2. Control }\end{array}$ & 56 & $12-17$ & $\begin{array}{l}\text { CBT reduced Internet overuse } \\
\text { and associated symptoms, and } \\
\text { improved time management } \\
\text { skills. Treatment gains were } \\
\text { observed at 6-month follow-up. }\end{array}$ & $\begin{array}{l}\text { Cohen's d=1.08 } \\
\text { (post) and } 1.35 \\
\text { (6-month } \\
\text { follow-up) }\end{array}$ \\
\hline $\begin{array}{l}\text { Han et al. } \\
(2009) \\
{[105]}\end{array}$ & $\begin{array}{l}\text { YIAS-K score of } 50 \\
\text { or higher }\end{array}$ & $\begin{array}{l}100 \% \text { reported a } \\
\text { video gaming } \\
\text { problem }\end{array}$ & $\begin{array}{l}\text { 1. Methylphenidate } \\
\text { ( } 8 \text { weeks) }\end{array}$ & 62 & $8-12$ & $\begin{array}{l}\text { Methylphenidate significantly } \\
\text { reduced severity of IA symptoms } \\
\text { and overall Internet usage. }\end{array}$ & NR \\
\hline $\begin{array}{l}\text { Han et al. } \\
(2010) \\
{[50]}\end{array}$ & $\begin{array}{l}>4 \mathrm{hr} \text { per day } / 30 \mathrm{hr} \\
\text { per week; YIAS } \\
\text { score of } 50 \text { or } \\
\text { higher; DSM-IV } \\
\text { criteria for substance } \\
\text { abuse }\end{array}$ & $\begin{array}{l}100 \% \text { reported a } \\
\text { video gaming } \\
\text { problem }\end{array}$ & $\begin{array}{l}\text { 1. Bupropion ( } 6 \text { weeks) } \\
\text { 2. Control }\end{array}$ & 19 & $17-29$ & $\begin{array}{l}\text { Bupropion reduced cravings for } \\
\text { video game play, total game play } \\
\text { time, and cue-induced brain } \\
\text { activity. }\end{array}$ & NR \\
\hline $\begin{array}{l}\text { Kim }(2008) \\
{[104]}\end{array}$ & $\begin{array}{l}\text { K-IAS (score not } \\
\text { specified) }\end{array}$ & $\mathrm{NC}$ & $\begin{array}{l}\text { 1. } \mathrm{R} / \mathrm{T} \text { group counseling } \\
(5 \text { weeks) } \\
\text { 2. Control }\end{array}$ & 25 & NR & $\begin{array}{l}10 \text { counseling sessions reduced } \\
\text { addiction symptoms and } \\
\text { increased self-esteem, as } \\
\text { compared to the control group. }\end{array}$ & NR \\
\hline $\begin{array}{l}\text { Shek et al. } \\
(2009)\end{array}$ & $\begin{array}{l}\text { YIAS-10 score of } 4 \\
\text { YIAS-8 score of } 5 \\
\text { YIAS-7 score of } 3 \\
\text { CIAS score of } 3\end{array}$ & $\mathrm{NC}$ & $\begin{array}{l}\text { 1. Multi-modal counseling } \\
\text { ( } 15 \text { to } 19 \text { months) }\end{array}$ & 59 & $11-18$ & $\begin{array}{l}\text { Counseling produced a decrease } \\
\text { in IA symptoms. Participants } \\
\text { reported high satisfaction with } \\
\text { the program. }\end{array}$ & NR \\
\hline $\begin{array}{l}\text { Su et al. }(2011) \\
{[108]}\end{array}$ & $\begin{array}{l}\text { YDQ score of } 5 ; \\
\text { Internet use of } 14 \\
\text { hours or more per } \\
\text { week }\end{array}$ & $\mathrm{NC}$ & $\begin{array}{l}\text { 1. HOSC-NE (one session) } \\
\text { 2. HOSC-LE (one session) } \\
\text { 3. HOSC-NI (one session) } \\
\text { 4. Control }\end{array}$ & 65 & NR & $\begin{array}{l}\text { All treatment groups } \\
\text { demonstrated significant } \\
\text { decreases in online activity } \\
\text { (hours) and YDQ scores after 1- } \\
\text { month. The "expert system" } \\
\text { treatments were the most } \\
\text { effective. }\end{array}$ & $\begin{array}{l}\text { Cohen's } \\
\text { d=0.72-0.82 } \\
\text { (YDQ score); } \\
\text { Cohen's } \\
\text { d=0.75-0.98 } \\
\text { (activity) }\end{array}$ \\
\hline $\begin{array}{l}\text { Young (2007) } \\
{[106]}\end{array}$ & $\begin{array}{l}\text { IAT (score not } \\
\text { specified) }\end{array}$ & $\begin{array}{l}10 \% \text { reported a video } \\
\text { gaming problem }\end{array}$ & 1. CBT (12 sessions) & 114 & NR & $\begin{array}{l}\text { CBT reduced most clients' } \\
\text { thoughts and behaviours related } \\
\text { to compulsive Internet use, at 6- } \\
\text { month follow-up. }\end{array}$ & NR \\
\hline
\end{tabular}

Abbreviations: CBT: Cognitive Behavior Therapy; CIAS: Chinese Internet Addiction Scale; DSM-IV: Diagnostic and Statistical Manual of Mental Disorders (4 ${ }^{\text {th }}$ Edition); HOSC: Healthy Online Self-Helping Center [NE: Natural Environment; LE: Learning Environment; NI: Non-Interactive]; IA: Internet Addiction; IAT: Internet Addiction Test; K-IAS: Korean Internet Addiction Scale; NC: Not clear; NR: Not reported; YDQ: Young's Diagnostic Questionnaire; YIAS: Young Internet Addiction Scale; R/T: Reality Training; YIASK: Young Internet Addiction Scale - Korean Version 
seek treatment, or seek treatment at a later stage for other psychological problems (e.g., depression) that develop after experiencing the severe negative consequences of gaming.

In South East Asia there appears to be significant demand for treatment for online-related problems including gaming addiction. The South Korean government has reportedly established a network of over 140 counseling centers for treatment of online addiction [104]. In Western countries, gaming addiction clinics have also started to emerge in places such as Holland and the UK $[13,16]$. There are also treatment groups that are modeled on 12-step self-help treatment (e.g., Online Gamers Anonymous)[13]. However, little detail is known about the treatment protocols or their efficacy.

King and colleagues [15] in a recent review of Internet and video game addiction treatment highlighted that most studies have failed to employ an objective measurement of game usage to confirm participants' self-reported usage at baseline or following intervention. Another issue is that many studies do not include a control group for betweengroup comparison. Treatment dose and duration also vary considerably across studies, for both pharmacological and non-pharmacological interventions. Unfortunately, the lack of consistent approaches to treating problematic video game play makes it difficult to produce any definitive conclusions as to the efficacy of treatment.

Table 2 presents a summary of the published literature on the treatment of video game addiction. The search protocol described in King, Delfabbro, Griffiths, and Gradisar ${ }^{16}$ was used to identify any recent papers not described in their paper. However, no additional papers were identified. All identified studies referred to video game addiction as a component or subtype of Internet addiction. Only three of the seven studies $[50,105,106]$ clearly stated the extent to which problem video gaming was a symptom or component of the Internet addiction. Only two studies [107,108] reported treatment effect sizes. Therefore, the clinical significance of treatment outcomes of published treatment studies is somewhat unclear.

Block [109] suggested that the diagnosis for online problems (including excessive gaming) should be included in the upcoming DSM-V as a compulsive-impulsive spectrum disorder although others have argued it should be considered a form of pathological technology use [110]. Publication of clinical criteria in a future DSM would facilitate and enhance standardization of research and treatment in the gaming studies field. It may also help minimize the potential for inappropriate clustering of clinical behaviors within an overly broad classification of problematic online behavior [15].

\section{GAMING ADDICTION: THE FUTURE?}

\section{Future Trends in Video Gaming}

The amount and the quality of research in the gaming addiction field has progressed much over the last decade but is still in its infancy compared to other more established behavioral addictions, such as pathological gambling. Before looking at the changes and trends over the last 30 years, this section briefly provides a considered (and somewhat theoretical) examination of what might happen in the gaming addiction field from a number of different standpoints (e.g., methodological, conceptual, technological). These are loosely modeled on the technological trends in gambling recently outlined by Griffiths [111].

- There is likely to be an even bigger increase in empirical research into problematic video game playing and video game addiction. This will of course be dependent on both appropriate funding streams and/or whether gaming addiction ends up being included in future psychiatric disorder classifications (e.g., DSM, ICD, etc.). Future research is likely to include more epidemiological and/or general population data on media use, leading to better insights into the onset and course of problematic video game play and addiction.

- Given the many different screening instruments that have been developed over the last decade, there is likely to be a refinement of video game addiction measures and greater consensus on its conceptualization, either as a single disorder and/or incorporated into other known disorders (e.g., impulse control disorder). This is also likely to lead to improved assessment tools based on such conceptualization(s).

- Measures of gaming use and subsequent behavior are likely to diversify in terms of media use, including social networking sites (SNS) and associated Internet resources [112]. Already, games such as Call of Duty and Battlefield 3 are being released with their own SNS (e.g., $C O D$ Elite) that track player behavior and provide feedback to players as to how to improve their game (thus functionally reinforcing video game play and thus have implications for excessive and/or potentially addictive play).

- Given the pressure on media enterprises to 'monetize' their business and look for different revenue streams, there is likely to be even greater media convergence between gaming and other more profit-making activities such as gambling [19,113]. Given the well established addictive potential of gambling, this may also have implications for the incidence of video game addiction.

- Gaming on the move is likely to be a big growth area that may have implications for excessive gaming via 'convenience' hardware such as handheld gaming consoles, PDA devices, mobile phones, tablet computers, and MP3 players.

- Given the fact that the Internet is gender-neutral, there is likely to be increasing feminization of gaming where increasing numbers of females not only engage in the playing of online games, but also develop problems as a result. Casual gaming online is already popular among females [114]. However, the biggest difference between male and female gaming is likely to be content-based (e.g., males may prefer competitive type gaming experiences whereas females may prefer co-operative type gaming experiences). 
- Given the increasing number of research teams in the gambling field being given direct access to gambling companies' behavioral tracking data [115], there is likely to be an increasing number of such collaborations in the gaming studies field.

- Given the increased importance of additional research into the structural and situational characteristics of consumptive behaviors (e.g., smoking nicotine, drinking alcohol, gambling, etc.), it is likely that research on design features within games and their psychological impact (including potential addiction) will increase as well. Such research has already begun [116-118].

- As the diagnosis of video game addiction becomes more legitimate in psychiatric and medical circles, it will lead to better randomized controlled trials on interventions for problematic video game play than the ones already carried out [16]. There is also likely to be an increase in the online medium itself being used as a treatment channel. The reasons that people like to engage in some online leisure activities (i.e., the fact that the online environment is non-face-to-face, convenient, accessible, affordable, anonymous, non-threatening, non-alienating, non-stigmatizing, etc.) may also be the very same reasons why people would want to seek advice, help and treatment online rather than in face-to-face situations $[119,120]$.

\section{CONCLUSIONS}

Based on the published empirical studies, and particularly those published over the last decade, it appears that in extreme cases, excessive video game playing can have potentially damaging effects upon individuals who appear to display compulsive and/or addictive behaviors similar to other more traditional addictions. However, the field has been hindered by the use of inconsistent and nonstandardized criteria to assess and identify problematic and/or addictive video game use. Furthermore, most studies' recruitment methods have serious sampling biases with an over-reliance on self-selected samples.

Despite these shortcomings, there are several noticeable trends that can be drawn from this review of problematic video game play and video game addiction.

- There has been a significant increase in empirical research decade by decade since the early 1980s.

- There has been a noticeable (and arguably strategic) shift in researching the mode of video game play. In the 1980s, research mainly concerned 'pay-to-play' arcade video games. In the $1990 \mathrm{~s}$, research mainly concerned stand alone (offline) video games played at home on consoles, PCs or handheld devices. In the 2000s, research mainly concerned online massively multiplayer video games.

- There has been a noticeable shift in how data are collected. Up until the early 2000s, data about video game behavior was typically collected face-to-face, whereas contemporary studies collect data online, strategically targeting online forums where gamers are known to (virtually) congregate. These samples are typically self-selecting and (by default) unrepresentative of the general population. Therefore, generalization is almost always one of the methodological shortcomings of this data collection approach.

- Survey study sample sizes have generally increased. In the 1980 s and 1990s, sample sizes were typically in the low hundreds. In the 2000s, sample sizes in their thousands - even if unrepresentative - are not uncommon.

- There has been a diversification in the way data are collected including experiments, physiological investigations, secondary analysis of existing data (such as that collected from online forums), and behavioral tracking studies.

- There has been increased research on adult (i.e., nonchild and non-adolescent) samples reflecting the fact that the demographics of gaming have changed.

- There has been increasing sophistication in relation to issues concerning assessment and measurement of problematic video game play and video game addiction. In the last few years, instruments have been developed that have more robust psychometric properties in terms of reliability and validity. However, there are still some concerns as many of the most widely used screening instruments were adapted from adult screens and much of the video game literature has examined children and adolescents. King and colleagues [15] assert that to enable future advances in the development and testing of interventions for video game-related problems, there must be some consensus among clinicians and researchers as to the precise classification of these problems.

Clearly, there exist a number of gaps in current understanding of problematic video game play and video game addiction. King et al. [3] note there is a need for epidemiological research to determine the incidence and prevalence of clinically significant problems associated with video game play in the broader population. There are too few clinical studies that describe the unique features and symptoms of problematic video game play and/or video game addiction. Most of the studies tend to examine problematic video play from the perspective of the individual. However, there is a small body of research suggesting that the characteristics of the video games themselves may have a role in the acquisition, development and maintenance of video game addiction. These studies have investigated the role of structural characteristics of video games in maintaining problem playing behavior [116$118]$, but there is little empirical research that examines why some individuals may be protected from developing excessive playing habits, or simply mature out of their problem playing behavior.

Another growing concern is the recent explosion of online and mobile gaming although, as yet, little research has been done. There are also strong links between online gaming, gambling, non-gambling fantasy games, roleplaying games, board games and card games. These may be an additional cause for concern as youth migrate from free gaming sites to online gambling sites as these have greater 
financial consequences and may lead not just to loss of time but to loss of money. It should also be noted that video game playing does not occur in a vacuum but is just one behavior engaged in alongside many others. To date, very few studies have been used to examine links between video games and other risk behaviors (e.g., gambling, drug and alcohol use, seatbelt use, poor school performance, conduct problems, truancy, delinquency, violence and sexual activity).

By examining the evolution of the literature on gaming addiction, this review has demonstrated that (i) past research was fundamentally different from more contemporary studies, (ii) the amount and quality of research has substantially increased over a short amount of time, and (iii) there are many potential avenues for future research including prevalence of problems, diagnostic and screening development, and treatment efficacy. While the current empirical base is relatively small, gaming addiction has become a more mainstream area for psychological and psychiatric research and is likely to become an area of significant importance given the widespread popularity of gaming.

\section{CONFLICT OF INTEREST}

The author(s) confirm that this article content has no conflicts of interest.

\section{ACKNOWLEDGEMENT}

Declared none.

\section{REFERENCES}

[1] Griffiths MD, Davies MNO. Videogame addiction: Does it exist? In Goldstein J, Raessens J (Eds.), Handbook of Computer Game Studies. Boston: MIT Press 2005; p.359-368.

[2] Griffiths MD. Diagnosis and management of video game addiction. New Directions in Addiction Treatment and Prevention 2008; 12: 27-41.

[3] King DL, Delfabbro PH, Griffiths MD. Recent innovations in video game addiction research and theory. Global Media Journal 4(1) [online] <http://www.commarts.uws.edu.au/gmjau/v4_2010_1/ daniel king_RA.html $>$ (2010).

[4] King D, Delfabbro PH, Griffiths MD. Video game addiction. In Miller P (Ed.), Encyclopedia of Addictive Behaviors. Oxford: Elsevier 2011

[5] Weinstein AM. Computer and video game addiction - A comparison between game users and non-game users. Am J Drug Alcohol Ab 2010; 36: 268-276.

[6] Griffiths MD. Online video gaming: What should educational psychologists know? Educational Psychology in Practice 2010; 26(1): 35-40.

[7] Kuss D.J. \& Griffiths, M.D. (2011a). Online gaming addiction: A systematic review. Int J Ment Health Addict, doi: 10.1007/s11469011-9318-5.

[8] Sublette VA, Mullan B. Consequences of play: A systematic review of the effects of online gaming. Int $J$ Ment Health Addict 2011; doi: 10.1007/s11469-010-9304-3.

[9] King DL, Delfabbro PH, Griffiths MD. The psychological study of video game players: Methodological challenges and practical advice. Int J Ment Health Addict 2009; 7: 555-562.

[10] Griffiths MD. The use of online methodologies in data collection for gambling and gaming addictions. Int $\mathrm{J}$ Ment Health Addict 2010; 8: 8-20.

[11] King DL, Delfabbro PH, Griffiths MD. Video game structural characteristics: A new psychological taxonomy. Int J Ment Health Addict 2010; 8: 90-106.
[12] King DL, Delfabbro PH, Griffiths MD. The role of structural characteristics in problem video game playing: A review. Cyberpsychology: Journal of Psychosocial Research on Cyberspace 4(1) [online] <http://www.cyberpsychology.eu/view.php? cisloclanku $=2010041401$ \&article $=6>(2010)$.

[13] Griffiths MD, Meredith A. Videogame addiction and treatment. J Contemp Psychother 2009; 39(4): 47-53.

[14] King DL, Delfabbro PH, Griffiths MD. Cognitive behavioural therapy for problematic video game players: Conceptual considerations and practice issues. Journal of CyberTherapy and Rehabilitstion 2010; 3: 261-273.

[15] King DL, Delfabbro PH, Griffiths MD. Clinical interventions for technology-based problems: Excessive Internet and video game use. Journal of Cognitive Psychotherapy 26: 43-56.

[16] King DL, Delfabbro PH, Griffiths MD, Gradisar M. Assessing clinical trials of Internet addiction treatment: A systematic review and CONSORT evaluation. Clin Psychol Rev 2011; 31: 1110-1116.

[17] Griffiths MD. Internet and video-game addiction. In Essau C (Ed.), Adolescent Addiction: Epidemiology, Assessment and Treatment. San Diego: Elselvier, 2008; p.231-267.

[18] Guan SA, Subrahmanyam K. Youth Internet use: risks and opportunities. Curr Opin Psychiatr 2009; 22: 351-356.

[19] King DL, Delfabbro PH, Griffiths MD. The convergence of gambling and digital media: Implications for gambling in young people. J Gambl Stud 2010; 26: 175-187.

[20] Sussman S, Lisha N, Griffiths MD. Prevalence of the addictions: A problem of the majority or the minority? Eval Health Prof 2011; 34: 3-56

[21] van Rooij AJ, Meerkerk G, Schoenmakers TM, Griffiths MD, van de Mheen D. Video game addiction and social responsibility, Addict Res Theory 2010; 18; 489-493.

[22] Albrecht U, Kirschner NE, Grüsser SM. Diagnostic instruments for behavioural addiction: an overview. Psycho-Social Medicine 4 [online] <http://www.ncbi.nlm.nih.gov/pmc/articles/PMC2736529/> (2007).

[23] Wood RTA. Problems with the concept of video game "addiction": Some case study examples. Int J Ment Health Addict 2008; 6: 169178.

[24] Yellowlees PM, Marks S. Problematic Internet use or Internet addiction? Comput Hum Behav 2007; 23: 1447-1453

[25] King DL, Delfabbro PH, Zajac IT. Preliminary validation of a new clinical tool for identifying problem video game playing. Int J Ment Health Addict 2011; 9: 72-87.

[26] Salguero RAT, Moran RMB. Measuring problem video game playing in adolescents. Addiction 2002; 97: 1601-1606.

[27] Kim MG, Kim J. Cross-validation of reliability, convergent and discriminant validity for the problematic online game use scale. Comput Hum Behav 2010; 26, 389-398.

[28] Skoric MM, Teo LLC, Neo RL. Children and video games: addiction, engagement, and scholastic achievement. Cyberpsychol Behav, 2009; 12: 567-572

[29] Charlton JP, Danforth IDW. Distinguishing addiction and high engagement in the context of online game playing. Comput Hum Behav 2007; 23: 1531-1548

[30] Griffiths MD. The role of context in online gaming excess and addiction: some case study evidence. Int J Ment Health Addict 2010; 8: 119-125.

[31] van Rooij AJ, Schoenmakers TM, van de Eijnden R, van de Mheen D. Compulsive Internet use: the role of online gaming and other Internet applications. J Adolescent Health 2010; 47: 51-57.

[32] Ross DR, Finestone DH, Lavin GK. Space Invaders obsession. Journal of the American Medical Association 1982; 248: 1117.

[33] Nilles JM. Exploring the world of the personal computer. Englewood Cliffs, NJ: Prentice Hall 1982.

[34] Soper WB, Miller MJ. Junk time junkies: An emerging addiction among students. School Counsellor 1983; 31: 40-43.

[35] Kuczmierczyk AR, Walley PB, Calhoun KS. Relaxation training, in vivo exposure and response-prevention in the treatment of compulsive video-game playing. Scandinavian Journal of Behaviour Therapy 1987; 16: 185-190. 
[36] Keepers, G.A. (1990). Pathologicical preoccupation with video games. Journal of the American Academy of Child and Adolescent Psychiatry, 29, 49-50.

[37] Shotton M. Computer addiction? A study of computer dependency. London: Taylor and Francis 1989.

[38] Widyanto L, Griffiths MD, Brunsden V. A psychometric comparison of the Internet Addiction Test, the Internet Related Problem Scale, and Self-Diagnosis. Cyberpsychology, Behavior, and Social Networking 2011; 14: 141-149.

[39] Brown RIF, Robertson S. Home computer and video game addictions in relation to adolescent gambling: Conceptual and developmental aspects. In Eadington WR, Cornelius J (Eds.), Gambling Behavior and Problem Gambling. Reno: University of Nevada Press 1993; p.451-471.

[40] Fisher SE. Identifying video game addiction in children and adolescents. Addict Behav 1994; 19: 545-553.

[41] Griffiths MD, Hunt N. Computer game playing in adolescence: Prevalence and demographic indicators. J Community Appl Soc 1995; 5: 189-193

[42] Griffiths MD, Hunt N. Dependence on computer games by adolescents. Psychol Rep 1998; 82: 475-480.

[43] Griffiths MD. Computer game playing in early adolescence. Youth Soc 1997; 29: 223-237

[44] Parsons, K. (1995, April). Educational places or terminal cases: Young people and the attraction of computer games. Paper presented at the British Sociological Association Annual Conference, University of Leicester.

[45] Phillips CA, Rolls S, Rouse A, Griffiths MD. Home video game playing in schoolchildren: A study of incidence and pattern of play. J Adolescence 1995; 18: 687-691

[46] American Psychiatric Association. Diagnostic and Statistical Manual for Mental Disorders (Fourth Edition). Washington, DC: American Psychiatric Association 1994.

[47] Charlton JP. A factor-analytic investigation of computer 'addiction' and engagement. Brit J Psychol 2002; 93: 329-344.

[48] Dworak M, Schierl T, Bruns T, Struder, HK. Impact of singular excessive computer game and television exposure on sleep patterns and memory performance of school-aged children. Pediatrics 2007; 120: $978-985$.

[49] Cultrara, A., \& Har-El, G. (2002). Hyperactivity-induced suprahyoid muscular hypertrophy secondary to excessive video game play: a case report. J Oral Maxil Surg, 60, 326-327.

[50] Han, D.H., Hwang, J.W., \& Renshaw, P.F. (2010). Bupropion sustained release treatment decreases craving for video games and cue-induced brain activity in patients with Internet video game addiction. Exp Clin Psychopharm, 18, 297-304.

[51] Hoeft F, Watson CL, Kesler SR, Bettinger KE, Reiss AL. Gender differences in the mesocorticolimbic system during computer game-play. Journal of Psychiatric Research 2008; 42: 253-258.

[52] Ko CH, Liu GC, Hsiao SM, Yen JY, Yang MJ, Lin WC, et al. (2009). Brain activities associated with gaming urge of online gaming addiction. J Psychiat Res 2009; 43: 739-747.

[53] Thalemann R, Wölfling K, Grüsser SM. Specific cue reactivity on computer game-related cues in excessive gamers. Behav Neurosci 2007; 12: 614-618.

[54] Han DH, Lee YS, Yang KC, Kim EY, Lyoo IK, Renshaw PF. Dopamine genes and reward dependence in adolescents with excessive internet video game play. J Addict Med 2007; 1: $133-138$

[55] Young K. Caught in the Net. Chichester: Wiley 1998

[56] Batthyány, D., Müller, K. W., Benker, F., \& Wölfling, K. (2009). Computer game playing: clinical characteristics of dependence and abuse among adolescents. Wiener Klinsche Wochenschrift, 121(1516), 502-509.

[57] Griffiths MD, Davies MNO, \& Chappell, D. (2004). Demographic factors and playing variables in online computer gaming. Cyberpsychol Behav 2004; 7: 479-487.

[58] King DL, Delfabbro P. Understanding and assisting excessive players of video games: a community psychology perspective. Australian Community Psychologist 2009; 21(1): 62-74.

[59] Liu M, Peng W. Cognitive and psychological predictors of the negative outcomes associated with playing MMOGs (massively multiplayer online games). Comput Hum Behav 2009; 25: 13061311.

[60] Peng W, Liu M. Online gaming dependency: a preliminary study in China. Cyberpsychology, Behavior and Social Networking 2010; 13: 329-333

[61] Peters CS, Malesky LA. Problematic usage among highly-engaged players of massively multiplayer online role playing games. Cyberpsychol Behav 2008; 11: 480-483.

[62] Rehbein F, Kleimann M, Mossle T. Prevalence and risk factors of video game dependency in adolescence: results of a German nationwide survey. CyberPsychology, Behavior and Social Networking 2010; 13: 269-277.

[63] Yee N. The demographics, motivations and derived experiences of users of massively-multiuser online graphical environments. PRESENCE: Teleoperators and Virtual Environments 2006; 15: 309-329.

[64] Yee N. The psychology of MMORPGs: emotional investment, motivations, relationship formation, and problematic usage. In Schroeder R, Axelsson A (Eds.), Avatars at work and play: Collaboration and interaction in shared virtual environments. London: Springer 2006; p.187-207.

[65] Allison SE, von Wahlde L, Shockley T, Gabbard GO. The development of the self in the era of the Internet and role-playing fantasy games. Am J Psychiat 2006; 163: 381-385.

[66] Lemmens JS, Valkenburg PM, Peter J. Psychosocial causes and consequences of pathological gaming. Comput Hum Behav 2011; 27: $144-152$

[67] Griffiths MD. Computer game playing and social skills: A pilot study. Aloma: Revista de Psicologia, Ciències de l'Educació i de l'Esport 2010; 27: 301-310.

[68] Zamani E, Kheradmand A, Cheshmi M, Abedi A, Hedayati N Comparing the social skills of students addicted to computer games with normal students. J Addict Health 2010; 2: 59-69.

[69] Chiu SI, Lee JZ, Huang DH. Video game addiction in children and teenagers in Taiwan. Cyberpsychol Behav 2004; 7: 571-581.

[70] Jeong EJ, Kim DW. Social activities, self-efficacy, game attitudes, and game addiction. Cyberpsychology, Behavior \& Social Networking 2011; 14: 213-221.

[71] Chan PA, Rabinowitz T. A cross-sectional analysis of video games and attention deficit hyperactivity disorder symptoms in adolescents. Annals of General Psychiatry 2006; 5(1): 16-26.

[72] Hussain Z, Griffiths MD. The attitudes, feelings, and experiences of online gamers: a qualitative analysis. Cyberpsychol Behav 2009; 12: $747-753$

[73] Hussain Z, Griffiths MD. Excessive use of massively-multi-player online role-playing games: a pilot study. Int J Ment Health Addict 2009; 7: 563-571.

[74] Graf WD, Chatrian GE, Glass ST, Knauss TA. Video-game related seizures: A report on 10 patients and a review of the literature. Pediatrics 1994; 3: 551-556.

[75] Maeda Y, Kurokawa T, Sakamoto K, Kitamoto I, Kohji U, Tashima S. Electroclinical study of video-game epilepsy. Dev Med Child Neurol 1990; 32: 493-500.

[76] Harding GFA, Jeavons PM. Photosensitive Epilepsy. London: Mac Keith Press 1994.

[77] Quirk JA, Fish DR, Smith SJM, Sander JW, Shorvon SD, Allen, PJ. First seizures associated with playing electronic screen games A com- munity based study in Great Britain. Ann Neurol 1995; 37: $110-124$

[78] Millett CJ, Fish DR, Thompson PJ. A survey of epilepsy-patient perceptions of video-game material/electronic screens and other factors as seizure precipitants. Seizure 1997; 6: 457-459.

[79] Chuang YC. Massively multiplayer online role-playing gameinduced seizures: a neglected health problem in Internet addiction. Cyberpsychol Behav 2006; 9: 451-456.

[80] Spence SA. Nintendo hallucinations: A new phenomenological entity. Irish J Psychol Med 1993; 10: 98-99.

[81] Schink JC. Nintendo enuresis. Am J Dis Child 1991; 145: 1094

[82] Corkery JC. Nintendo power. Am J Dis Child 1990; 144: 959.

[83] Shimai S, Yamada F, Masuda K, Tada M. TV game play and obesity in Japanese school children. Percept Motor Skill 1993; 76: 1121-1122. 
[84] Deheger M, Rolland-Cachera MF, Fontvielle AM. Physical activity and body composition in 10 year old French children: Linkages with nutritional intake? Int J Obesity 1997; 21: 372-379.

[85] Johnson B, Hackett AF. Eating habits of 11-14-year-old schoolchildren living in less affluent areas of Liverpool, UK. J Hum Nutr Diet 1997; 10: 135-144.

[86] Vandewater EA, Shim M, Caplovitz AG. Linking obesity ad activity level with children's television and game use. JAdolescence 2004; 27: 71-85

[87] McCowan TC. Space Invaders wrist. New Engl J Med 1981; 304: 1368.

[88] Miller DLG. Nintendo neck. Can Med Assoc J 1991; 145: 1202.

[89] Reinstein, L. (1983). De Quervain's stenosing tenosynovitis in a video games player. Arch Phys Med Rehab, 64, 434-435.

[90] Brasington R. Nintendinitis. New Engl J Med 1990; 322: 14731474.

[91] Casanova J, Casanova J. Nintendinitis. J Hand Surg 1991; 16: 181.

[92] Siegal IM. Nintendonitis. Orthopedics 1991; 14: 745.

[93] Loftus GA, Loftus EF. Mind at play: The psychology of video games. New York: Basic Books 1983

[94] Cleary AG, Mckendrick H, Sills JA. Hand-arm vibration syndrome may be associated with prolonged use of vibrating computer games. Brit Med J 2002; 324: 301.

[95] Mirman MJ, Bonian VG. "Mouse elbow": A new repetitive stress injury. J Am Osteopath Assoc 1992; 92: 701.

[96] Mehroof M, Griffiths MD. Online gaming addiction: the role of sensation seeking, self-control, neuroticism, aggression, state anxiety, and trait anxiety. Cyberpsychol Behav 2010; 13: 313-316.

[97] Caplan SE, Williams D, Yee N. Problematic internet use and psychosocial well-being among MMO players. Comput Hum Behav 2009; 25: 1312-1319.

[98] Kim, E. J., Namkoong, K., Ku, T., \& Kim, S. J. (2008). The relationship between online game addiction and aggression, self-control and narcissistic personality traits. Eur Psychiat, 23, 212-218.

[99] Porter G, Starcevic V, Berle D, Fenech P. Recognizing problem video game use. Aust NZ J Psychiat 2010; 44: 120-128

[100] Ko CH, Yen JY, Chen CC, Chen SH, Yen CF. Gender differences and related factors affecting online gaming addiction among Taiwanese adolescents. J Nerv Ment Dis 2005; 193: 273-277.

[101] Parker JDA, Taylor RN, Eastabrook JM, Schell SL, Wood LM. Problem gambling in adolescence: relationships with internet misuse, gaming abuse and emotional intelligence. Pers Indiv Differ 2008; 45: 174-180.

[102] Han DH, Lee YS, Na C, Ahn JY, Chung US, Daniels MA, et al. The effect of methylphenidate on Internet video game play in children with attention-deficit/hyperactivity disorder. Compr Psychiat 2009; 50: 251-256.

[103] Woog K. A survey of mental health professionals clinical exposure to problematic computer use. Unpublished study [online] http://www.wooglabs.com/ (2004).

[104] Kim J. The effect of a R/T group counselling program on the Internet addiction level and self-esteem of Internet addiction university students. International Journal of Reality Therapy 2008; 17: 4-12.

[105] Han DH, Lee YS, Na C, Ahn JY, Chung US, Daniels MA, Haws CA, Renshaw PF. The effect of methylphenidate on Internet video game play in children with attention-deficit/hyperactivity disorder. Compr Psychiat 2009; 50: 251-256.

[106] Young K. Cognitive behavior therapy with Internet addicts: Treatment outcomes and implications. Cyberpsychol Behav 2007; 10: 671-679.

[107] Du Y, Jiang W, Vance A. Longer term effect of randomized, controlled group cognitive behavioral therapy for Internet addiction in adolescent students in Shanghai. Aust NZ J Psychiat 2010; 44: 129-134.

[108] Su W, Fang X, Miller JK, Wang Y. Internet-based intervention for the treatment of online addiction for college students in China: A pilot study of the Healthy Online Self-Helping Center. CyberPsychology, Behavior, \& Social Networking 2011; 14: 497-503.
[109] Block JJ. Issues for DSM-V: Internet addiction [Editorial]. Am J Psychiat 2008; 165: 306-307.

[110] Gentile DA, Choo H, Liau A, Sim T, Li D, Fung D, Khoo A Pathological video game use among youths: A two-year longitudinal study. Pediatrics 2011; 127: 319-329.

[111] Griffiths MD. Technological trends and the psychosocial impact on gambling. Casino and Gaming International 2011; 7(1): 77-80.

[112] Kuss DJ, Griffiths MD. Addiction to social networks on the internet: A literature review of empirical research. Int J Environ Public Health 2011; 8: 3528-3552.

[113] Griffiths MD. Digital impact, crossover technologies and gambling practices. Casino and Gaming International 2008; 4(3): 37-42.

[114] Lewis A, Griffiths MD. Confronting gender representation: A qualitative study of the experiences and motivations of female casual-gamers. Aloma: Revista de Psicologia, Ciències de l'Educació i de l'Esport 2011; 28: 245-272.

[115] Griffiths MD, Whitty MW. Online behavioural tracking in Internet gambling research: Ethical and methodological issues. International Journal of Internet Research Ethics 2010; 3: 104-117.

[116] Wood RTA, Griffiths MD, Chappell D, Davies MNO. The structural characteristics of video games: A psycho-structural analysis. Cyberpsychol Behav 2004; 7: 1-10.

[117] Westwood D, Griffiths MD. The role of structural characteristics in video game play motivation: A Q-Methodology Study, Cyberpsychology, Behavior and Social Networking 2010; 13: 581585.

[118] King DL, Delfabbro PH, Griffiths MD. The role of structural characteristics in problematic video game play: An empirical study. Int J Ment Health Addict 2011; 9: 320-333.

[119] Griffiths MD, Cooper G. Online therapy: Implications for problem gamblers and clinicians, Brit J Guid Couns 2003; 13: 113-135.

[120] Griffiths MD. (2005). Online therapy for addictive behaviors. Cyberpsychol Behav 2005; 8: 555-561.

[116] Grüsser SM, Thalemann R, Albrecht U, Thalemann CN Exzessive Computernutzung im Kindesalter-Ergebnisse einer psychometrischen Erhebung. Wiener Klinische Wochenschrift 2005; 117(5-6): 188-195.

[117] Grüsser SM, Thalemann R, Griffiths MD. Excessive computer game playing: Evidence for addiction and aggression? Cyberpsychol Behav 2007; 10: 290-292.

[118] Gentile D. Pathological video game use among youth ages 8 to 18: A national study. Psychol Sci 2009; 20: 594-602.

[119] Thomas NJ, Martin FH. Video-arcade game, computer game and Internet activities of Australian students: participation habits and prevalence of addiction. Aust J Psychol 2010; 62(2): 59-66.

[121] Fisher S. Identifying video game addiction in children and adolescents. Addict Behav 1994; 19: 545-553.

[122] Griffiths MD, Hunt N. Dependence on computer games by adolescents. Psychol Rep 1998; 82: 475-480.

[123] Lee C, Han S. Development of the scale for diagnosing online game addiction. Paper presented at the 3rd WSEAS/IASME International Conference on Educational Technologies, Arcachon, France, 2007.

[124] Wan CS, Chiou WB. The motivations of adolescents who are addicted to online games: A cognitive perspective. Adolescence 2007; 42: 179-197.

[125] Xu Z, Yuan, Y. The impact of motivation and prevention factors on game addiction. Paper presented at the Special Interest Group on Human-Computer Interaction 2008

[126] Lemmens JS, Valkenburg, PM, Peter J. Development and validation of a game addiction scale for adolescents. Media Psychol 2009; 12: 77-95.

[127] Arnesen AA. Video game addiction among young adults in Norway: Prevalence and health. Faculty of Psychology Unpublished manuscript. University of Bergen. Bergen, Norway 2010 .

[128] Choo H, Gentile DA, Sim T, Li D, Khoo A, Liau AK. Pathological video-gaming among Singaporean youth. Annals Academy of Medicine Singapore 2010; 39, 822-829.

[129] van Rooij AJ, Schoenmakers TM, Vermulst AA, van den Eijnden $\mathrm{R}$, van de Mheen D. Online video game addiction: Identification of addicted adolescent gamers. Addiction 2011; 106: 205-212. 
[130] Wölfling K, Müller K, Beutel M. Reliabilität und Validität der Skala zum Computerspielverhalten (CSV-S). Psychotherapie, Psychosomatik, Medizinische Psychologie 2010; doi: 10.1055/s0030-1263145.

[131] Lemmens JS, Valkenburg PM, Peter J. Psychosocial causes and consequences of pathological gaming. Comput Human Behav 2011; 27: 144-152.

[132] Lemmens JS, Valkenburg PM., Peter J. The effects of pathological gaming on aggressive behavior. J Youth Adolescence 2011; 40: 38-47.

[133] Mentzoni RA, Brunborg GS, Molde H, Myrseth H, Skouveroe KJM, Hetland J, Pallesen S. Problematic video game use:
Estimated prevalence and associations with mental and physical health. Cyberpsychology, Behavior \& Social Networking 2011; 14: 591-596.

[134] Hussain Z, Griffiths MD, Baguley T. Online gaming addiction: Classification, prediction and associated risk factors. Addict Res Theory 2012; 20: 359-371..

[135] Shek DTL, Tang VMY, Lo CY. Evaluation of an Internet addiction treatment program for Chinese adolescents in Hong Kong. Adolescence 2009; 44: 359-373. 